\title{
Persistence and productivity of orchardgrass and orchardgrass/alfalfa mixtures as affected by cutting height
}

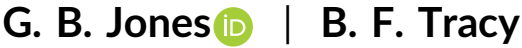

Department of Crop and Soil Environmental Sciences, Virginia Tech, Blacksburg, VA, USA

Correspondence

B. F. Tracy, Department of Crop and Soil Environmental Sciences, Virginia Tech, Blacksburg, VA, USA.

Email: bftracy@vt.edu

\begin{abstract}
Cutting height is an important factor controlling the yield and persistence of grass swards harvested for conserved feed. The objective of this experiment was to determine the effect of four cutting heights $(5,10,15$ and $20 \mathrm{~cm})$ on the yield, composition and productivity based on deviation from a size/density compensation line for swards of orchardgrass (Dactylis glomerata L.) and an orchardgrass/alfalfa (Medicago sativa L.) mixture harvested nine times over three growing seasons. Yield was greatest for the $5 \mathrm{~cm}$ cutting height through the course of the experiment but ground cover of orchardgrass declined. Prior to the final harvest, tiller weight and density were determined. The 10-, 15- and $20-\mathrm{cm}$ treatments fell on an apparent size/density compensation line with slope $-1.779\left(R^{2}=.99 ; p=.008\right)$ while the 5 $\mathrm{cm}$ treatment fell considerably below that line indicating a reduction in productivity or relative persistence. Harvest at $10 \mathrm{~cm}$ appears to optimize yield while maintaining stand productivity in infrequently harvested orchardgrass swards.
\end{abstract}

KEYWORDS

cutting height, Dactylis glomerata, cocksfoot, persistence, size/density compensation

\section{1 | INTRODUCTION}

It is well known that excessively low cutting height can have deleterious effects on mown perennial grass swards (Brink, Casler, \& Martin, 2010; Stapledon \& Milton, 1930; Volesky \& Anderson, 2007). It has been suggested that cutting height is a major factor linked to recently observed decline in orchardgrass (cocksfoot; Dactylis glomerata) stands in the North American Mid-Atlantic area (Clark, 2009; Smith \& Saylor, 2012). This may be because of the adoption of rotary disc mowers by many hay producers in recent decades (Adams, 1996), and because the design of these mowers allows for a lower cutting height. In determining mowing height for perennial grasses, producers face a trade-off between increased yield at lower heights and increased persistence at higher heights. Thus, a common recommendation has been to increase cutting height to increase stubble leaf area index and water-soluble carbohydrate content to improve regrowth and sward persistence. This, however, may be at the expense of short-term yield.

Persistence of perennial grasses is defined as the ability of each tiller to produce on offspring annually such that members of the population replace themselves (Edwards \& Chapman, 2011). Many studies use either tiller density (Raese \& Decker, 1966; Volesky \& Anderson, 2007) or per cent ground cover (Brink et al., 2010; Smith, Jaques, \& Balasko, 1973) to determine the effects of various treatments on the persistence of swards. It is also known, however, that tiller density alone is not always related to the yield of swards (Davies, 1988). Tiller weight is required in addition to density in order to determine the productivity of grass stands. For example, swards with low tiller weight need to achieve high tiller number in order to maintain high productivity, while swards with low tiller number need to reach a high tiller weight to maintain high productivity.

Size/density compensation (SDC) theory dictates that swards of various tiller densities and weights will maximize leaf area along a $-3 / 2$ self-thinning line (Matthew, Lemaire, Sackville Hamilton, \& Hernandez Garay, 1995; Sackville Hamilton, Matthew, \& Lemaire, 1995). It has been proposed that deviation from the apparent SDC line for otherwise similarly managed swards can be used as a measure of relative stand productivity (Hernandez Garay, Matthew, \& 

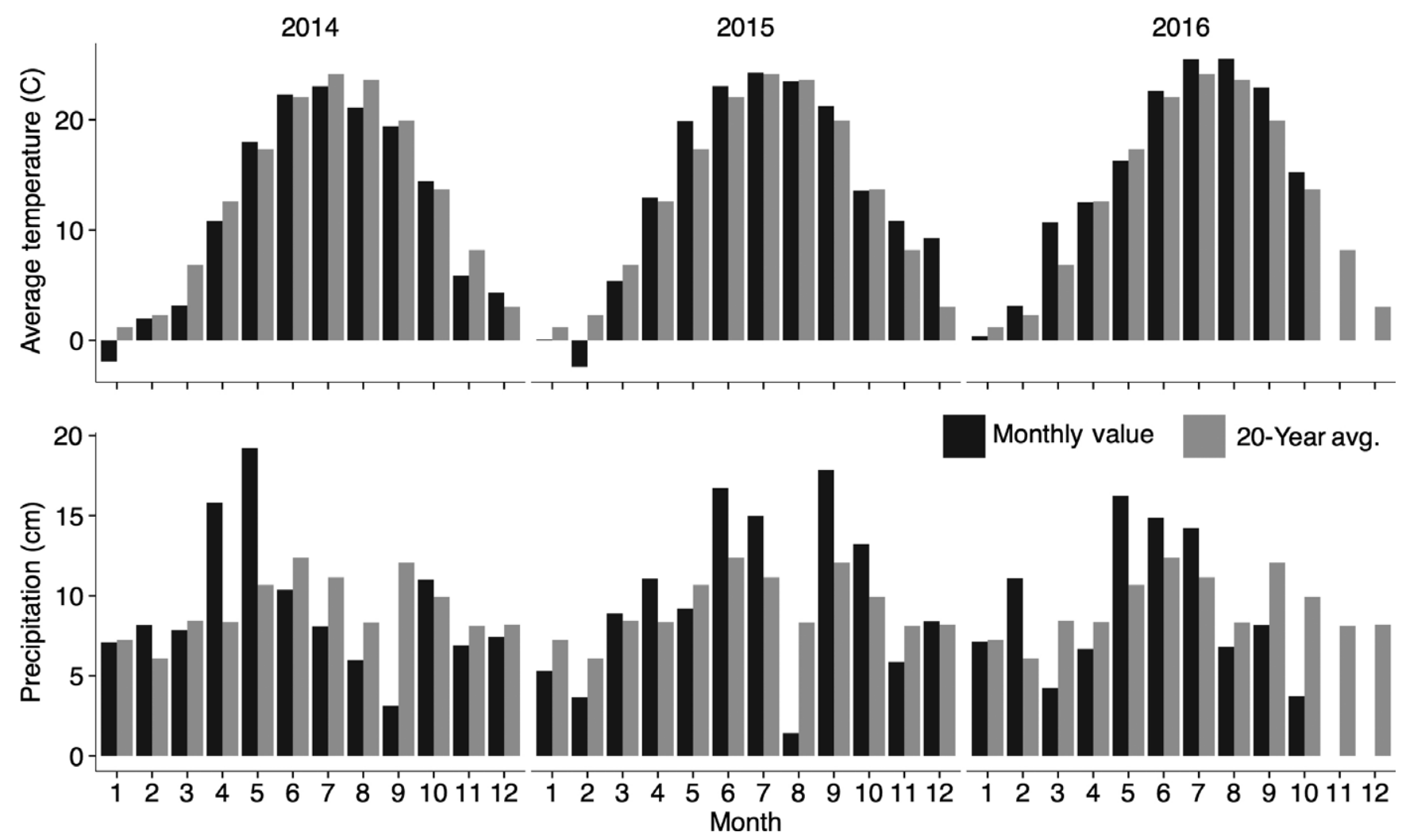

FIGURE 1 Average monthly air temperature and precipitation accumulation over the experimental period and 20-year averages in Orange, VA

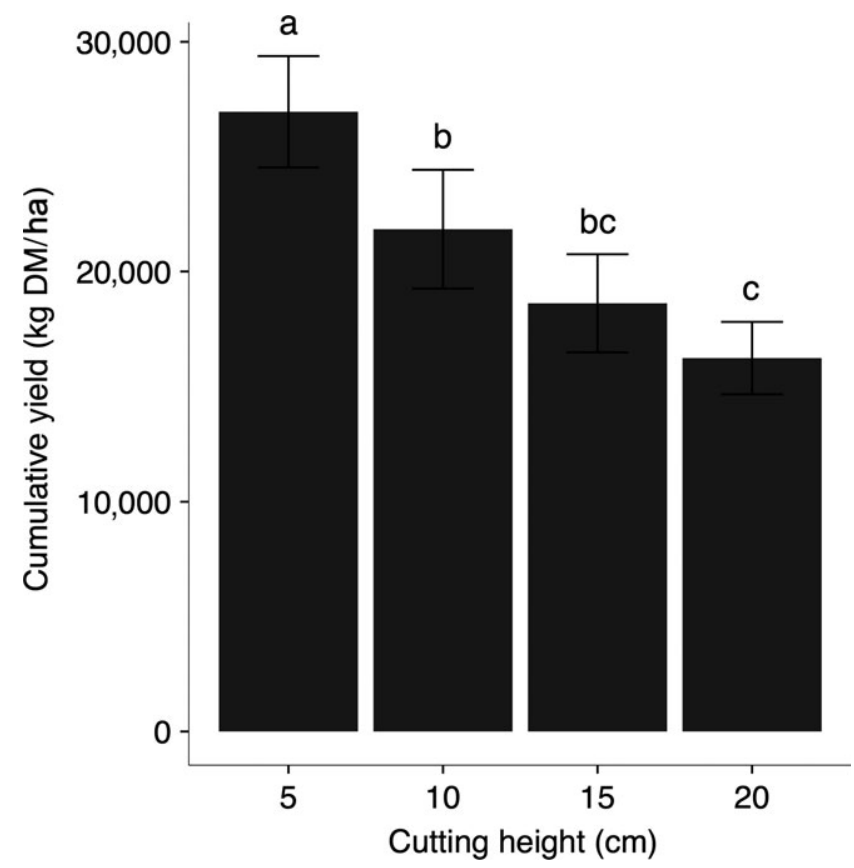

FIGURE 2 Effect of four cutting heights on cumulative yield of nine harvests. Average of pure orchardgrass and orchardgrass/alfalfa treatments. Bars marked with differing letter indicated significant differences $(p<.05)$

Hodgson, 1999). This has been implemented in several forage systems including perennial ryegrass (Lolium perenne L.) mini-swards (Hernandez Garay et al., 1999), rhodesgrass (Chloris gayana Kunth.) mini-
TABLE 1 Abbreviated ANOVA table for dry-matter yield $(n=8)$ $* p<0.05 ; * * p<0.01 ; * * *<<0.001$

\begin{tabular}{|lrrc|}
\hline Source & \multicolumn{1}{c}{ df } & F Ratio & \multicolumn{1}{c}{$p$-value } \\
\hline Height & 3 & 28.64 & $<.0001^{* * *}$ \\
\hline Mix & 1 & 0.33 & .587 \\
\hline Cutting & 2 & 353.29 & $<.0001^{* * *}$ \\
\hline Year (linear) & 1 & $208 \cdot 20$ & $<.0001^{* * *}$ \\
\hline Height $\times$ Mix & 3 & 0.56 & .646 \\
\hline Height $\times$ Cutting & 6 & 2.78 & $.012^{*}$ \\
\hline Height $\times$ Year & 3 & 1.16 & .323 \\
\hline Mix $\times$ Cutting & 2 & 5.89 & $.003^{* *}$ \\
\hline Mix $\times$ Year & 1 & 0.09 & .769 \\
\hline Cutting $\times$ Year & 2 & 27.05 & $<.0001^{* * *}$ \\
\hline Plot & 63 & & \\
\hline Block & 7 & & \\
\hline Block $\times$ Height & 21 & & \\
\hline Block $\times$ Mix & 7 & & \\
\hline Experimental error & 453 & & \\
\hline
\end{tabular}

swards (Martinez Calsina, Agnusdei, Assuero, \& Perez, 2012), fieldgrown tall fescue (Schedonorus arundinaceus (Schreb.) Dumort.) and prairie grass (Bromus catharticus Vhal) (Scheneiter \& Assuero, 2010).

A better understanding of the trade-off between persistence and productivity of mown perennial grass swards is required for improved management decisions. To our knowledge, the SDC of 
First

Second

Third

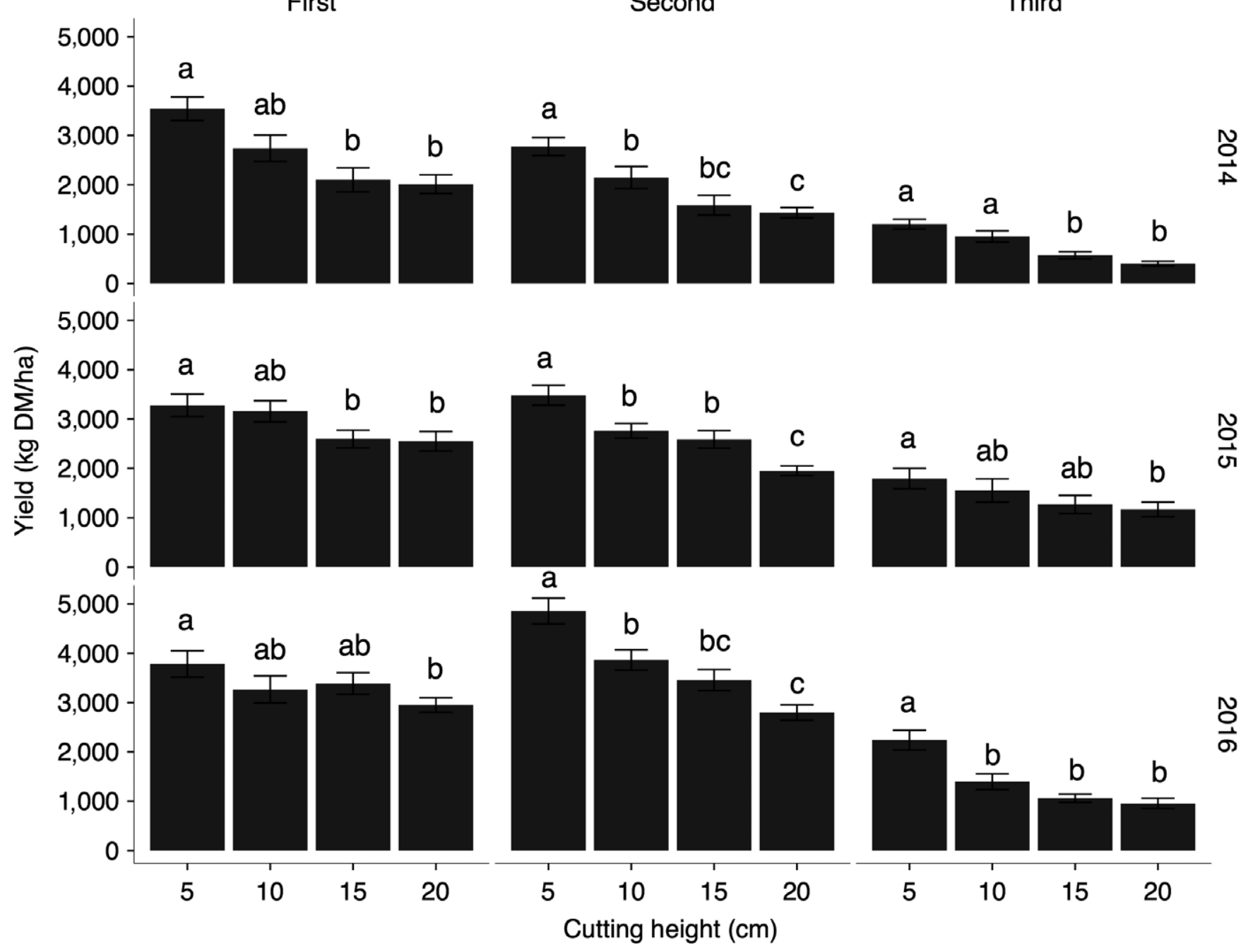

FIGURE 3 The effect of cutting height on the dry-matter yield of nine harvests of orchardgrass and orchardgrass/alfalfa plots. Bars with different letters differ significantly within a time point $(p<.05 ; n=8)$

mown swards has not been evaluated in North America. Deviation from an SDC line may provide clarity in the effects of cutting height on orchardgrass productivity. Thus, the objective of this experiment was to evaluate the yield, composition and SDC-corrected productivity of pure orchardgrass and an orchardgrass/alfalfa mixture harvested to four cutting heights over three growing seasons.

\section{2 | METHODS}

\subsection{Site and establishment}

This experiment was conducted during the 2014-2016 growing seasons at the Northern Piedmont Center near Orange, VA, USA $\left(38^{\circ}\right.$ $13^{\prime} 26.10^{\prime \prime} \mathrm{N}, 78^{\circ} 07^{\prime} 13.08^{\prime \prime} \mathrm{W}, 156 \mathrm{~m}$ a.s.l.). Weather data were collected at a weather station on the site. The soil was Davidson loam (fine, kaolinitic, thermic Rhodic Kandiudults). Paired plots $(12 \times 4 \mathrm{~m})(n=8)$ of pure orchardgrass (cv. "Benchmark Plus") at $15 \mathrm{~kg}$ seed/ha and orchardgrass/alfalfa (OG/Alf) mixture (15 kg OG and $15 \mathrm{~kg}$ Alf (cv. "Evermore")/ha) were planted in September 2012 into tilled seedbeds where the previous crop was switchgrass (Panicum virgatum L.). The paired plots were separated by a 1-m alley, and the eight replicates were separated by $10-30 \mathrm{~m}$. Plots were fertilized and limed according to Virginia Tech Soil Test recommendation at establishment. During the 2013 growing season, the plots were allowed to establish and were mown to $15 \mathrm{~cm}$ twice (May and September), but no data were collected.

For 2014-2016, pure OG plots were fertilized with $67 \mathrm{~kg} \mathrm{~N} / \mathrm{ha}$ as urea $\left(\mathrm{CO}\left(\mathrm{NH}_{2}\right)_{2}\right)$ and $165 \mathrm{~kg} \mathrm{~K} / \mathrm{ha}$ as $\mathrm{KCl}$ during mid-March. An additional $67 \mathrm{~kg} \mathrm{~N} / \mathrm{ha}$ was applied to pure OG plots following first cutting. The OG/Alf plots received $165 \mathrm{~kg} \mathrm{~K} \mathrm{ha}^{-1} \mathrm{year}^{-1}$ as $\mathrm{KCl}$ in mid-March, but no $\mathrm{N}$ was applied.

\subsection{Harvest and composition}

Four cutting height treatments $(5,10,15$ and $20 \mathrm{~cm})$ were designated for each block. First cutting was made near the emergence of the seedhead (R1; Moore et al., 1991) which corresponded to May 
19, 12 and 16 for 2014, 2015 and 2016 respectively. Second cutting was made approximately 60 days later (July 11, 20 and 18 for 2014, 2015 and 2016, respectively), and third cutting was made approximately 90 days thereafter (October 24, 8 and 20 for 2014, 2015 and 2016 respectively). Harvest of a $1.3 \times 3 \mathrm{~m}$ swath was made at the designated cutting height with a sickle bar-type Swift Forage Harvester (Swift Current, SK, Canada) with height adjustment made at each block. The location and height of swaths were consistent across the nine harvests. At harvest, a grab sample of forage was collected, then dried and weighed for dry-matter determination. Yields are presented on a dry-matter basis but were not corrected for inclusion of non-planted species.

Prior to each harvest, visual per cent cover was determined for a $0.5-\mathrm{m}^{2}(50 \times 100 \mathrm{~cm})$ quadrat in each plot using a modified Daubenmire method (1968). Cover was classed into orchardgrass, alfalfa, weeds and bare ground. The major weed species observed was Securigera varia L. with rare observance of Pancum virgatum L., Rumex sp., Apocynum cannabinum L. and Convolvulus arvensis $\mathrm{L}$.

\section{3 | Tiller harvest}

Tillers and stems were destructively harvested prior to the final cutting in 2016 to assess the cumulative effect of the cutting treatments on those populations. A $0.1-\mathrm{m}^{2}(20 \times 50 \mathrm{~cm})$ quadrat was randomly selected from each plot in six of the blocks. Orchardgrass and alfalfa were harvested at ground level with a

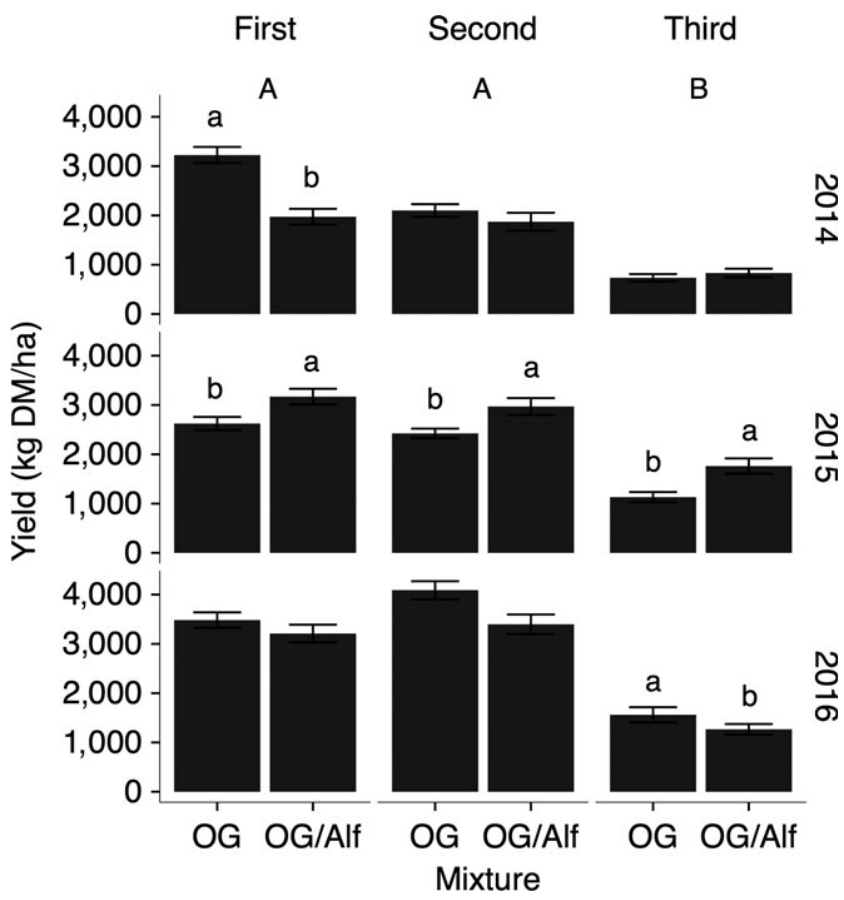

FIGURE 4 The effect of planted mixture and cutting on the drymatter yield of nine harvests. Bars with different lowercase letters differ significantly within a time point $(p<.05)$. Columns with different uppercase letters indicate significant differences among cuttings $(p<.05)$ razor blade. Samples were initially sorted into orchardgrass, alfalfa and dead material categories. Phytomers were removed from orchardgrass tillers if more than $50 \%$ of the leaf area was senescent or necrotic from pathogen damage. Orchardgrass tillers and alfalfa stems were counted. Fifty randomly selected orchardgrass tillers per OG plot were dissected into leaf blade and pseudostem (mostly leaf sheaths and stem) fractions. All tissue was dried at $60^{\circ} \mathrm{C}$ for $48 \mathrm{hr}$ in a forced air oven. Leaf:pseudostem and leaf:nonleaf (non-leaf material included the pseudostem and senescent fractions) ratios were calculated following Hernandez Garay et al. (1999).

To evaluate the effect of cutting height on tiller size and density, the $\log _{10}$ tiller weight (living + senescent) and $\log _{10}$ tiller density were plotted. It has been theoretically shown (Matthew et al., 1995) and experimentally confirmed (Hernandez Garay et al., 1999) that the distance a treatment lies from an arbitrarily placed SDC line with slope $-3 / 2$ provides a measure of relative stand productivity. The slope of the SDC line is also known to be steeper (closer to $-5 / 2$ ) in defoliated swards (Martinez Calsina et al., 2012; Matthew et al., 1995). The slope of the apparent SDC line was calculated by major axis regression of the log tiller weight by log tiller density for the 10- to $20-\mathrm{cm}$ cutting height treatments. The distance each point lies from this apparent SDC line was calculated.

\subsection{Statistical analysis}

Statistical analysis was conducted with JMP Pro 13 (SAS Inst., Cary, NC, USA) and R version 3.02 (R Development Core Team, 2013). The experiment was designed as a split-block design $(n=8)$. Within each replication, cutting heights were blocked across the OG and OG/Alf treatments to control for error associated with adjusting the mower height. The main ANova model was as follows:

$$
\begin{aligned}
Y_{\mathrm{ijklm}}= & \mu+\alpha_{\mathrm{i}}+B_{\mathrm{j}}+(\alpha B)_{\mathrm{ij}}+\beta_{\mathrm{k}}+(\beta B)_{\mathrm{kj}}+(\alpha \beta)_{\mathrm{ik}}+\gamma_{\mathrm{l}}+\lambda_{\mathrm{m}} \\
& +(\alpha \gamma)_{\mathrm{il}}+(\alpha \lambda)_{\mathrm{im}}+(\beta \gamma)_{\mathrm{kl}}+(\beta \lambda)_{\mathrm{km}}+(\gamma \lambda)_{\mathrm{lm}}+R_{\mathrm{ijk}}+E_{\mathrm{ijklm}}
\end{aligned}
$$

where $Y=$ dry-matter yield; $\alpha=$ cutting height effect $(i=1,2,3,4)$; $B=$ block effect $(j=1,2, \ldots 8) ; \beta=$ mixture effect $(k=1,2) ; \gamma=$ cutting effect $(I=1,2,3) ; \lambda=$ year effect $(m=1,2,3) ; R=$ plot block effect; $(\alpha \mathrm{B})_{\mathrm{ij}}=$ split-block error $\mathrm{I} ;(\beta \mathrm{B})_{\mathrm{kj}}=$ split-block error II; and $E=$ experimental error. A similarly constructed model without provision for the effect of multiple cuttings was used to analyse tiller data. Model residuals were evaluated and found to be normally distributed. Effects with $p<.05$ were considered significant. Tukey's HSD was used to determine mean separation.

\section{3 | RESULTS}

\subsection{Weather data}

The average monthly temperature and precipitation accumulation were measured and compared to 20-year averages (1995-2015; Figure 1). Average temperature during the 2014 growing season was slightly less than the historic average, close to the historic average 
First

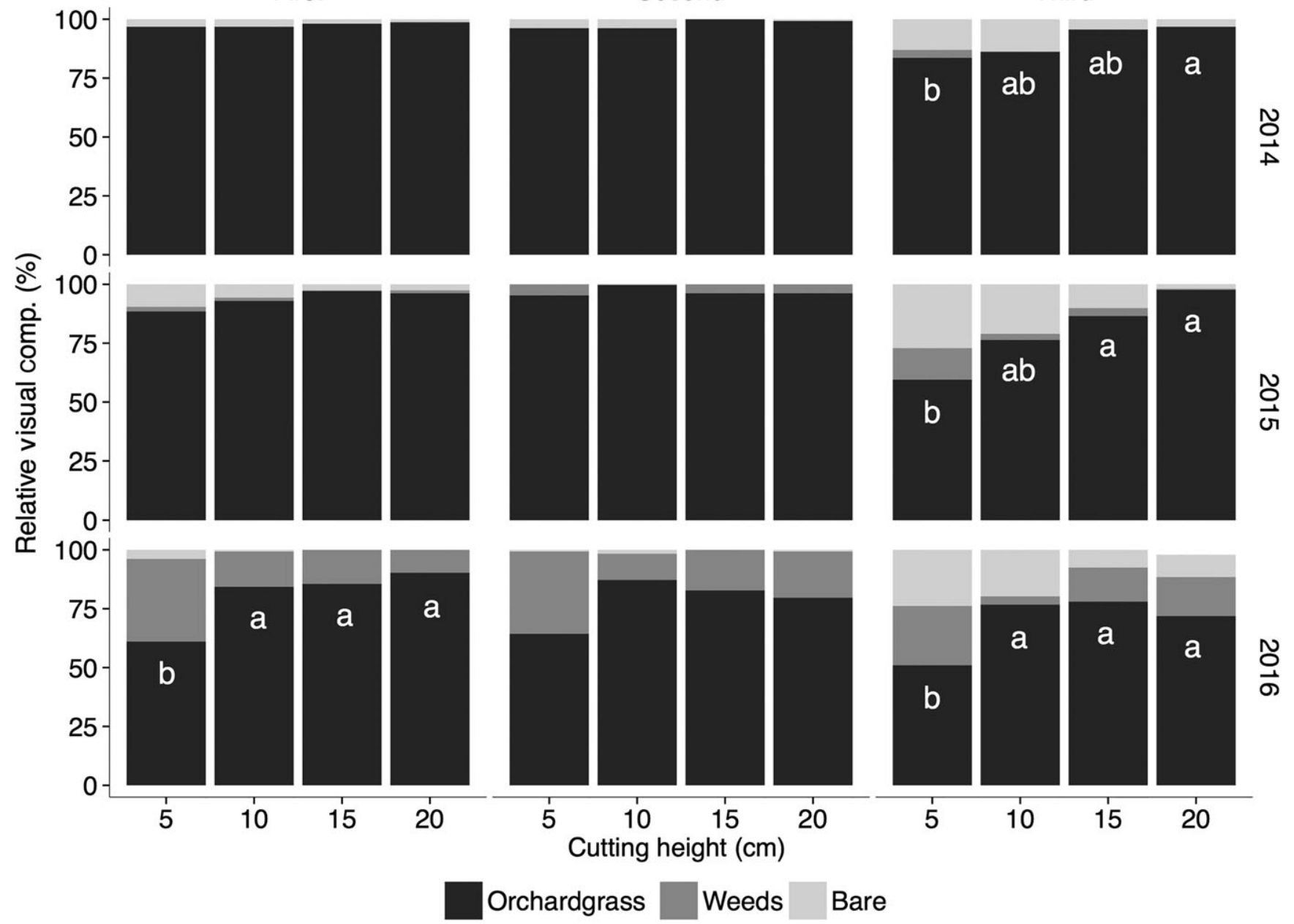

FIGURE 5 Effect of cutting height on visual composition of orchardgrass plots prior to each harvest. Bars with different letters indicate significantly different proportions of orchardgrass within a time point $(p<.05, n=8)$

for 2015 and slightly greater than the historic average for 2016. Early season precipitation exceeded the historic average in 2014 but was well below the historic average for June to September. Accumulated precipitation exceeded the historic average for most months of the 2015 growing season except for August. In 2016, March and April were relatively dry, May-July had precipitation exceeding the historic average, and August, September and October were dry again.

\subsection{Herbage yield}

Herbage yield was significantly affected $(p<.0001)$ by cutting height (Figure 2) but did not differ significantly between OG and OG/Alf treatments $(p=.587)$ and there was no cutting height $\times$ mixture interaction (Table 1). The yield differed and interacted by both cutting and year (Table 1). The slope of the linear effect of year was 522.7. The effect of cutting height differed by the cutting but not by year (Figure 3 ), and the effect of mixture differed by cutting $(p=.003)$ but not by year $(p=.769$; Figure 4$)$. The lowest cutting height removed a greater proportion of standing biomass throughout the experiment. While the degree of separation among the treatment means varied among the nine harvests, in every case the $5-\mathrm{cm}$ cutting height yielded significantly more than the $20 \mathrm{~cm}$ height (Figure 3). Third cutting yielded less across years than did cuttings 1 and 2 (Figure 4). For cutting 1 of 2014 and cutting 3 of 2016 OG significantly outyielded OG/Alf, but for the three cuttings of 2015 OG/Alf outyielded the OG plots (Figure 4). Cumulative yield also differed by cutting height but not by mixture. The $5-\mathrm{cm}$ cutting height treatment had the greatest cumulative yield and the $15-$ and $20-\mathrm{cm}$ treatments had the lowest (Figure 2).

\section{3 | Composition}

The proportion of orchardgrass ground cover was the focus of evaluation of sward composition. The proportion of orchardgrass cover differed significantly with cutting height, mixture and harvest $(p<.05)$. Significant interactions of cutting height $\times$ harvest and mixture $\times$ harvest were detected $(p<.01)$, but a cutting height $\times$ mixture interaction was not found. Individual ANOVA 
First

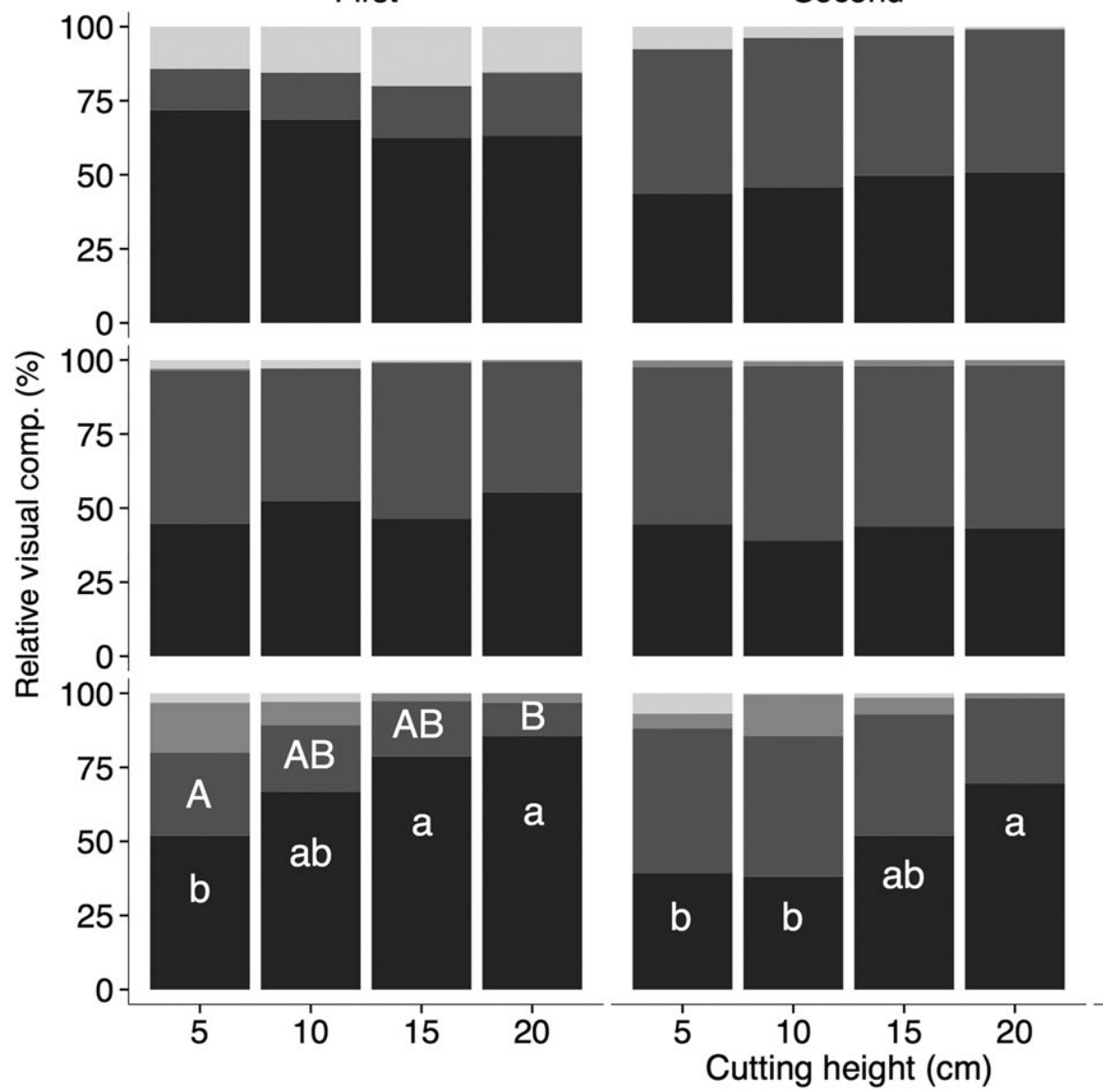

Third

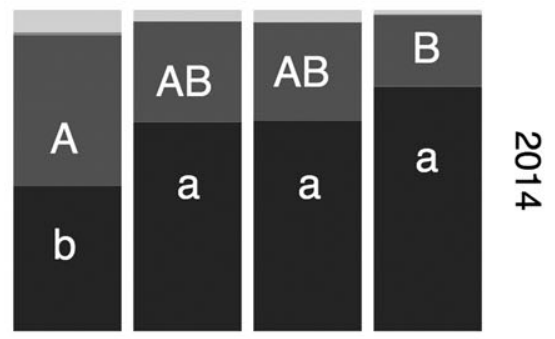

Orchardgrass Alfalfa Weeds Bare

FIGURE 6 Effect of cutting height on visual composition of orchardgrass/alfalfa plots prior to each harvest. Bars with different lowercase letters indicate significantly different proportions of orchardgrass within a time point $(p<.05 ; n=8)$. Bars with different uppercase letters indicate significantly different proportions of alfalfa within a time point $(p<.05 ; n=8)$

TABLE 2 Effect of cutting height on orchardgrass mass (living + senescent)(OG mass; $\mathrm{g} / \mathrm{m}^{2}$ ), tiller population density (density; tillers $/ \mathrm{m}^{2}$ ), leaf mass $\left(\mathrm{g} / \mathrm{m}^{2}\right)$, tiller weight (g/tiller), leaf:pseudostem ratio (L:S ratio) and leaf:non-leaf ratio (L:NL ratio) where "leaf" included green leaf and "non-leaf" included pseudostem and senescent components

\begin{tabular}{lcccccc} 
Cutting Height $(\mathbf{c m})$ & OG mass & Density & Tiller weight & Leaf mass & L:S ratio & L:NL ratio \\
\hline 5 & $200.8 \mathrm{~b}$ & 733 & $0.303 \mathrm{c}$ & $44.3 \mathrm{~b}$ & $2.277 \mathrm{a}$ & $0.380 \mathrm{a}$ \\
10 & $453.6 \mathrm{a}$ & 1050 & $0.454 \mathrm{bc}$ & $58.6 \mathrm{ab}$ & $1.792 \mathrm{ab}$ & $0.183 \mathrm{~b}$ \\
15 & $503.9 \mathrm{a}$ & 913 & $0.581 \mathrm{ab}$ & $62.2 \mathrm{a}$ & $1.428 \mathrm{ab}$ & $0.172 \mathrm{~b}$ \\
20 & $572.8 \mathrm{a}$ & 802 & $0.746 \mathrm{a}$ & $55.0 \mathrm{ab}$ & $1.326 \mathrm{~b}$ & $0.131 \mathrm{~b}$ \\
\hline -value & .002 & .182 & $<.001$ & .036 & .029 \\
\hline
\end{tabular}

Rows with different letters with a column differ significantly $(p<.05 ; n=6)$.

within each harvest indicated that the proportion of orchardgrass present in OG plots was significantly reduced for the lowest cutting height as compared to the highest height for third cutting in 2014 and 2015 and first and third cuttings in 2016 (Figure 5). Similarly, individual ANOVA within each harvest indicated that the proportion of orchardgrass present in OG/Alf plots was significantly reduced for the lowest cutting height as compared to the highest for third cuttings of 2014 and 2015 and first and second cuttings of 2016 (Figure 6). ANOVA assessing cutting height differences in alfalfa cover within harvests found increased alfalfa cover in the $5-\mathrm{cm}$ treatment as compared to the $20-\mathrm{cm}$ treatment for harvest 32014 and harvest 12016 (Figure 6). 


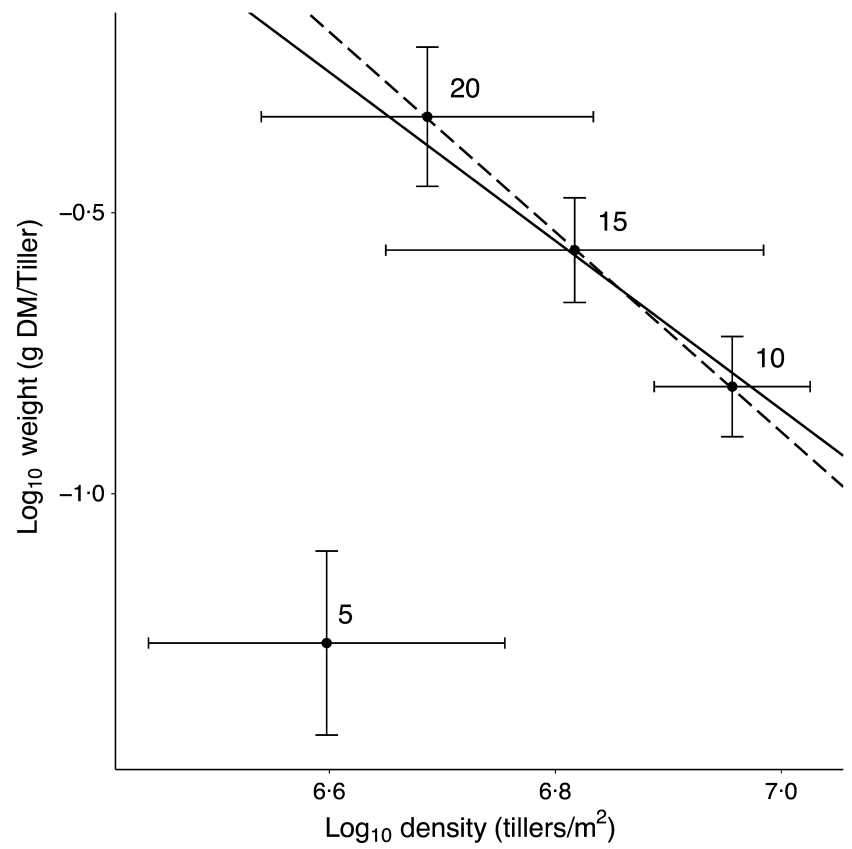

FIGURE 7 Log tiller weight (living + senescent) and log tiller density $( \pm$ SEM) for OG plots as affected by cutting height $(\mathrm{cm})$ prior to the final harvest in 2016. The dashed line is the apparent SDC line for the system fit by major axis regression $(y=-1.779 x$ $\left.+11.563 ; p=.0082 ; n=3 ; R^{2}=.999\right)$. The solid line is an arbitrarily placed SDC line with slope $-3 / 2$

TABLE 3 The effect of cutting height on the distance from the apparent SDC line $(y=-1.779 x+11.563 ; p=.008)$ (See Figure 7)

\begin{tabular}{|ll}
$\begin{array}{l}\text { Cutting } \\
\text { height }(\mathrm{cm})\end{array}$ & $\begin{array}{l}\text { Distance to the } \\
\text { apparent SDC line }\end{array}$ \\
\hline 5 & -0.537 \\
10 & 0.001 \\
15 & 0.004 \\
\hline 20 & -0.001 \\
\hline
\end{tabular}

Negative values indicate a relative reduction in sward productivity.

\section{4 | Sward components and size/density compensation}

Sward and tiller components were evaluated from the OG plots prior to the final harvest of the experiment. The mass of living + senescent orchardgrass differed among the cutting heights with the $5-\mathrm{cm}$ treatment having lower mass than the other three treatments (Table 2). Tiller density did not differ significantly among the treatments but tended $(p=18)$ to be highest for the 10-cm treatment and lowest for the $5-\mathrm{cm}$ treatment (Table 2). The weight of individual tillers was reduced in the $5-\mathrm{cm}$ treatment as compared to 15and $20-\mathrm{cm}$ treatments, and the $20-\mathrm{cm}$ treatment had the greatest tiller weight (Table 2). The orchardgrass leaf mass differed among the treatments with the lowest leaf mass for the $5-\mathrm{cm}$ treatment, the highest leaf mass for the $15-\mathrm{cm}$ treatment and intermediate mass for $10-$ and $20-\mathrm{cm}$ treatments (Table 2). Leaf:pseudostem ratio was greatest for the $5-\mathrm{cm}$ treatment and lowest for the $20-\mathrm{cm}$ treatment
(Table 2). Leaf:non-leaf ratio was significantly higher for the $5-\mathrm{cm}$ treatment as compared to the others (Table 2).

The mean tiller weight and tiller density by cutting height were plotted in log-log space (Figure 7). The apparent slope of the SDC line was -1.778 based on the $10-$ to $20-\mathrm{cm}$ treatments. The distance between treatment means and the apparent SDC line were calculated. The 10-, 15- and 20-cm treatments fell on the apparent SDC line while the $5-\mathrm{cm}$ treatment showed a large negative deviation from the line (Table 3).

\section{DISCUSSION}

Cutting to $5 \mathrm{~cm}$ resulted in the highest yields in this system for both pure orchardgrass and the orchardgrass/alfalfa mixture over 3 years. It is clear that harvesting to a low cutting height will remove a greater proportion of aerial biomass and this has been shown in several experiments with orchardgrass where yields were greater at lower cutting heights (Brink et al., 2010; Mitchell, 1967; Raese \& Decker, 1966; Sprague \& Garber, 1950; Volesky \& Anderson, 2007). Low cutting heights, however, remove a greater proportion of photosynthetic leaf area and non-structural carbohydrates (Ward and Blaser, 1961). In some cases, the stress caused by low cutting has reduced sward yield over the course of experiments (Harrison \& Hodgson, 1939; Stapledon \& Milton, 1930; Volesky \& Anderson, 2007) although this effect is often related to harvest frequency and the number of years of treatment application.

The differences in yield among harvests and years are likely related to the weather conditions present during the regrowth from the previous harvest and also to $\mathrm{N}$ supply. Nitrogen fertilizer was applied to the pure OG plots prior to first and second cuttings each year, but additional $\mathrm{N}$ was not amended prior to third cutting. This explains the reduced yield for third cutting. The linear effect of year had a positive slope, indicating that any change in sward dynamics or weather did not deleteriously affect yield during the course of the experiment. Yield was greater for the OG/Alf only during 2015. This may be explained by the greater proportion of alfalfa in the swards during that year (Figure 5). Dry weather in August may have contributed, at least partly, to the increased proportion of alfalfa to orchardgrass. Deep taproots of alfalfa plants allow relatively greater drought tolerance than in many forage grasses (Barnes \& Sheaffer, 1995).

Proportions of orchardgrass and alfalfa cover differed among harvest dates which would be expected with varying weather conditions. Cutting height only had an effect on orchardgrass cover in four of nine harvests for both pure OG and OG/Alf stands. In all cases, the proportion of orchardgrass was reduced in the $5-\mathrm{cm}$ treatment as compared to the $20-\mathrm{cm}$ treatment. A reduction in ground cover or tiller density at low cutting heights has been observed in other experiments with orchardgrass (Brink et al., 2010; Mitchell, 1967; Volesky \& Anderson, 2007), and is likely due to stress caused by the removal of photosynthetic leaf area and non-structural carbohydrates. Alfalfa cover differed among the cutting heights in two of 
nine harvests and was significantly greater for the $5-\mathrm{cm}$ treatments as compared to $20-\mathrm{cm}$ treatments in both cases. The differences in morphology of orchardgrass and alfalfa explain this response. The meristematic tissue and non-structural carbohydrates in tillers of orchardgrass are located above the soil surface (Christie \& McElroy, 1995; Turner, Donaghy, Lane, \& Rawnsley, 2007), while the buds of alfalfa are located near or just below the soil surface and non-structural carbohydrates are located in the roots (Barnes \& Sheaffer, 1995)). Because of this, Blaser et al. (1986) predicted improved regrowth for orchardgrass at higher cutting heights and improved regrowth for alfalfa lower cutting heights. It is expected that this is the main cause of the differences seen here as well.

Orchardgrass yields remained high during 3 years of cutting at $5 \mathrm{~cm}$, but ground cover of orchardgrass was reduced at low cutting heights. A finer level of observation, than stand scores, is required to evaluate relative changes in productivity and persistence of these swards. Several parameters were measured from destructively harvested tillers prior to the final cutting. Total orchardgrass mass was reduced at the $5 \mathrm{~cm}$ cutting height because a greater proportion of those plants were removed at each harvest while leaves and pseudostem were allowed to accumulate below the mowing height of the higher height treatments. Tiller density was not significantly affected by cutting height but tended to be lowest at the $5 \mathrm{~cm}$ height and greatest at the $10 \mathrm{~cm}$ height. This matches to some extent the ground cover observation from these treatments. The mass per tiller was proportional to the cutting height treatments. Leaf mass was reduced for the $5 \mathrm{~cm}$ cutting height, but the leaf: pseudostem ratio was greatest for the lowest cutting height. The leaf:non-leaf ratio was also highest for the $5-\mathrm{cm}$ treatment. Higher cutting heights allow for senescence and accumulation of leaves below that cutting height and also cause a shift in morphology wherein the collar region of tillers is elevated causing an increased proportion of pseudostem to leaves. This trend was also found in perennial ryegrass mini-swards harvested to several cutting heights (Hernandez Garay et al., 1999).

Neither tiller size nor tiller density alone provides adequate information to be able to infer sward productivity or persistence. This is because of the phenomenon of the size/density compensation in which optimal sustainable leaf area for a site can be achieved with many small tillers or a few large ones. The solutions for the expected size/density compensation of unmanaged swards grow up to and then along a -3/2 line (Davies, 1988; Yoda, Kira, Ogawa, \& Hozumi, 1963) assuming constant tiller geometry. Matthew et al. (1995) proposed a modification to this self-thinning equation for defoliated swards which will differ in tiller geometry (leaf area $\mathrm{cm}^{-3}$ tissue). They proposed that a steeper SDC line $(-5 / 2)$ is expected for defoliated swards if not corrected for differing tiller volume. Here, we found the slope of the apparent SDC line to be -1.778 , somewhat steeper than $-3 / 2$. This matches with SDC slopes greater than -3 / 2 found for perennial ryegrass (Hernandez Garay et al., 1999) and rhodesgrass (Martinez Calsina et al., 2012).

The distance that otherwise similar treatments fall from a SDC line can be used as a measure of relative sward productivity
(Hernandez Garay et al., 1999; Martinez Calsina et al., 2012). The 10-, 15- and 20-cm treatments were located along the apparent SDC slope found in this experiment while the $5-\mathrm{cm}$ treatment deviated from this line in the negative direction. This indicates that even after approximately 90 days of regrowth, the $5 \mathrm{~cm}$ cutting height was not able to achieve the expected tiller weight given the tiller density. This limitation to accumulation of tiller mass and leaf area indicates that low cutting height caused the orchardgrass plants to reach their limit of phenotypic plasticity; this caused a reduction in tiller weight and density and thus a reduction in productivity of the $5-\mathrm{cm}$ treatment and a relative reduction in persistence of those swards.

\section{5 | CONCLUSIONS}

Cutting height is an important determining factor in the yield and persistence of orchardgrass swards. We found higher yields at the lowest cutting height through out the duration of the experiment, even as the orchardgrass ground cover declined. The use of tiller mass and density to determine the apparent slope of the size/density compensation line for these swards indicated that cutting heights of $10 \mathrm{~cm}$ or greater were required to maintain productivity and that the productivity of swards repeatedly harvested to $5 \mathrm{~cm}$ was reduced. Were this experiment carried out for further growing seasons, it would be expected that yields would decline for plots cut to $5 \mathrm{~cm}$. It was also observed that orchardgrass/alfalfa mixtures without fertilizer $\mathrm{N}$ yielded as well as pure orchardgrass fertilized with $120 \mathrm{~kg} \mathrm{~N} \mathrm{ha}^{-1} \mathrm{year}^{-1}$. While forage quality, not measured in this experiment, is an important determinant of the economic value of harvested feed, the similar yields without the additional cost of added $\mathrm{N}$ fertilizer may help to reduce the cost of production while continuing to provide forage mass to livestock or for sale. These results reaffirm the recommendation to harvest orchardgrass at $10 \mathrm{~cm}$ to optimize yield and persistence when harvested infrequently for conserved forage.

\section{REFERENCES}

Adams, R. K. (1996). The present and future of alfalfa harvesting equipment. Proceedings of 26th National Alfalfa Symposium in conjunction with the 26th California Alfalfa Symposium. December 9-10 1996, San Diego, California.

Barnes, D., \& Sheaffer, C. (1995). Alfalfa. In R. Barnes, D. Miller, \& C. J. Nelson (Eds.), Forages: An Introduction to Grassland Agriculture, Vol. 1. Ames, lowa: lowa State University Press.

Blaser, R. E., Hammes, R. C., Fontenot, J. P., Bryant, H. T., Polan, C. E., Wolf, D. D., ... Moore, J. S. (1986). Forage-Animal Management Systems. Virginia. Agricultural Experiment Station Bulletin, 86-87.

Brink, G. E., Casler, M. D., \& Martin, N. P. (2010). Meadow fescue, tall fescue and orchardgrass response to defoliation management. Agronomy Journal, 102, 667-674.

Christie, B., \& McElroy, A. (1995). Orchardgrass. In R. Barnes, D. Miller, \& C. J. Nelson (Eds.), Forages: An Introduction to Grassland Agriculture, Vol. 1. Ames, lowa: lowa State University Press.

Clark, B. (2009). Orchardgrass Situation Overview. The Mid-Atlantic Orchardgrass Taskforce. Retrieved from: http://midatlanticorchardgra sstaskforce.pbworks.com/f/Orchardgrass+Overview+of+the+Problem. pdf Accessed on 11/5/16. 
Daubenmire, R. F. (1968). Plant communities: A textbook of plant synecology. New York: Harper \& Row.

Davies, A. (1988). The regrowth of grass swards. In M. Jones, \& A. Lazenby (Eds.), The Grass Crop: The Physiological Basis for Production. New York: Chapman and Hall.

Edwards, G., \& Chapman, D. (2011). Plant responses to defoliation and relationship with pasture persistence. Pasture persistence. Grassland Research and Practice Series, 15, 39-46.

Harrison, C. M., \& Hodgson, C. W. (1939). Response of certain perennial grasses to cutting treatments. Agronomy Journal, 31, 418-430.

Hernandez Garay, A., Matthew, C., \& Hodgson, J. (1999). Tiller size/density compensation in perennial ryegrass miniature swards subjects to differing defoliation heights and a proposed productivity index. Grass and Forage Science, 54, 347-356.

Martinez Calsina, L., Agnusdei, M. G., Assuero, S. G., \& Perez, H. (2012). Size/density compensation in Chloris Guyana Kunth cv. Fine Cut subjected to different defoliation regimes. Grass and Forage Science, 76, 255-262.

Matthew, C., Lemaire, G., Sackville Hamilton, N. R., \& Hernandez Garay, A. (1995). A modified self-thing equation to describe size/density relationships for defoliated swards. Annals of Botany, 76, 579-587.

Mitchell, W. H. (1967). Influence of cutting heights, irrigation, and nitrogen on the growth and persistence of orchardgrass (p. 364). Bulletin No: University of Delaware Agricultural Experiment Station.

Moore, K. J., Moser, L., Vogel, K., Waller, S., Johnson, B., \& Pedersen, F. (1991). Describing and quantifying growth stages of perennial forage grasses. Agronomy Journal, 83, 1073-1077.

R Development Core Team (2013). R: A language and environment for statistical computing. Vienna, Austria: R Foundation for Statistical Computing. ISBN 3-900051-07-0, URL http://www.R-project.org/

Raese, J. T., \& Decker, A. M. (1966). Yield, stand persistence, and carbohydrate reserves of perennial grasses as influenced by spring harvest stage, stubble height and nitrogen fertilization. Agronomy Journal, 58, 322-326.

Sackville Hamilton, N. R., Matthew, C., \& Lemaire, G. (1995). In defense of the $-3 / 2$ boundary rule: $A$ re-evaluation of self-thinning concepts and status. Annals of Botany, 76, 569-577.
Scheneiter, J., \& Assuero, S. (2010). Tiller population density and productivity in tall fescue and prairie grass swards. Ciencia e Investigació Agraria, 37, 35-44.

Smith, D., Jaques, A., \& Balasko, J. (1973). Persistence of several temperate grasses grown with alfalfa and harvested two, three, or four times annually at two stubble heights. Crop Science, 13, 553-556.

Smith, S. R., \& Saylor, L. (2012). Determining the effect of mowing height and fertility on orchardgrass yield and persistence. American Forage and Grassland Council Proceedings and Abstracts.

Sprague, V. G., \& Garber, R. J. (1950). Effect of time and height of cutting and nitrogen fertilization on the persistence of legume and production of orchard grass-ladino and bromegrass-ladino associations. Agronomy Journal, 42, 586-592.

Stapledon, R. G., \& Milton, W. E. J. (1930). The effects of different cutting and manurial treatments on the tiller development of cocksfoot. Welsh Journal of Agriculture, 6, 166-174.

Turner, L. R., Donaghy, D. J., Lane, P. A., \& Rawnsley, R. P. (2007). Distribution of water-soluble carbohydrate reserves in the stubble of prairie grass and orchardgrass plants. Agronomy Journal, 99, 591-594.

Volesky, J. D., \& Anderson, B. E. (2007). Defoliation effects on production and nutritive value of four irrigated cool-season perennial grasses. Agronomy Journal, 99, 494-500.

Ward, C.Y., \& Blaser, R.E. (1961). Carbohydrate food reserves and leaf area of orchardgrass. Corp Science, 1, 366-370.

Yoda, K., Kira, T., Ogawa, H., \& Hozumi, K. (1963). Self-thinning in overcrowded pure stands under cultivated and natural conditions. Journal of Biology - Osaka City University, 14, 107-129.

How to cite this article: Jones GB, Tracy BF. Persistence and productivity of orchardgrass and orchardgrass/alfalfa mixtures as affected by cutting height. Grass Forage Sci. 2017;00:1-9. https://doi.org/10.1111/gfs.12309 